\title{
New rapidly solidified aluminium alloys for elevated temperature applications on aerospace structures
}

\author{
Y. BARBAUX and G. PONS \\ Aerospatiale, Centre Commun de Recherches Louis Blériot, BP. 76, 92152 Suresnes cedex, France
}

\begin{abstract}
:
This paper presents the results of a cooperative study between AEROSPATIALE, DASSAULT AVIATION, BRITISH AEROSPACE, AlENIA, IMPERIAL COLLEGE, CEREM, ALPOCO, RAUFOSS A/S, CENIM AND THE UNIVERSITY OF PISA supported by the CEC under BRITE EURAM contract BREU $0356 \mathrm{C}$ which aims at developping a new Aluminium alloy for use at 250 $300^{\circ} \mathrm{C}$ by Rapid Solidification / Powder Metallurgy technology.

Tensile and creep properties at temperatures up to $350^{\circ} \mathrm{C}$, fracture toughness and corrosion results on 11 alloys from the $\mathrm{Al}-\mathrm{Fe}-\mathrm{V}, \mathrm{Al}-\mathrm{Fe}-\mathrm{Mo}, \mathrm{Al}-\mathrm{Cr}-\mathrm{Ni}$ and $\mathrm{Al}-\mathrm{Mn}-\mathrm{Ni}$ systems are presented and discussed. Their stability for long exposures at temperatures up to $350^{\circ} \mathrm{C}$ is demonstrated on the basis of fine microstructural investigations and mechanical tests.

The cross effect of the Iron content and the powder size distribution is detailed in the case of the gas atomization process for the Al-Fe-V system.

The results obtained on the most promising products are detailed and compared to those available on existing 8009 and 8019 alloys.

Potential applications on aerospace structures are described.
\end{abstract}

Keywords : Aluminium Alloys - Rapid Solidification - Powder Metallurgy - Elevated Temperature - Aerospace

\section{INTRODUCTION}

In 1991 AEROSPATIALE, DASSAULT AVIATION, BRITISH AEROSPACE, ALENIA, IMPERIAL COLLEGE, CEREM, ALPOCO, RAUFOSS A/S, CENIM AND THE UNIVERSITY OF PISA started a cooperative development programme supported by the CEC [1] with the objective of developping a new Aluminium alloy, competing with Titanium up to $300^{\circ} \mathrm{C}$ as far as elastic and mechanical properties are concerned. The new alloy was expected to increase the field of application of aluminium alloys, restricted today to the range of temperatures up to $150^{\circ} \mathrm{C}$, on aircraft structures.

In particular the driving force for such a development work was the preparation of the new high speed civil transport aircraft project (mach 2.2 to 3 ). However potential applications on subsonic aircrafts and helicopters had also been identified and benefits in terms of cost and weight savings had been estimated.

Rapid Solidification / Powder Metallurgy technology was selected as the only way to elaborate aluminium alloys suitable for these elevated temperatures. At the time when the programme was defined many studies were already going on in Europe and in the United States of America, mainly based on the Aluminium - Iron, Aluminium - Chromium or Aluminium - Manganese - Nickel systems, and some "commercial" products started to be available.

However, most of these developments were oriented towards engines requirements, which means different target properties (temperature range, creep strength, fatigue and damage tolerance properties) and different product forms (sheets and extrusions versus forgings). 
It was thus decided to base the programme on a further optimization of the already investigated systems, taking into account the requirements specific to airframe structure applications.

\section{WORK PROGRAMME}

The development work programme was divided in two major steps :

step 1 - Influence of the chemical composition

$\underline{\text { step } 2}$ - Influence of the manufacturing process

In the first step 12 chemical compositions of 4 alloy systems have been selected on the basis of existing data [2], [3], [4], [5], [6], [7]. These were :

$$
\begin{aligned}
& \mathrm{Al}-\mathrm{Fe}-\mathrm{V} \text { system : } \mathrm{Al}-8,5 \mathrm{Fe}-1,5 \mathrm{~V} \\
& \text { Al }-8,5 \mathrm{Fe}-2 \mathrm{~V} \\
& \mathrm{Al}-8,5 \mathrm{Fe}-2,5 \mathrm{~V} \\
& \mathrm{Al} \text { - Fe - Mo system: } \quad \mathrm{Al}-8,5 \mathrm{Fe}-1,5 \mathrm{Mo} \\
& \mathrm{Al}-8,5 \mathrm{Fe}-2 \mathrm{Mo} \\
& \text { Al - 8,5Fe - 2,5Mo }
\end{aligned}
$$

The $\mathrm{Al}-\mathrm{Fe}-\mathrm{V}$ and $\mathrm{Al}-\mathrm{Fe}$ - Mo systems were corresponding to an objective of improvement of mechanical properties as compared to existing alloys. The increase of strength would allow the replacement of high strength Ti 6-4 alloy, extending the potential market for the developped alloy. The choice of the 8 compositions was aiming at precising the influence of the 3rd alloying element (Vanadium or Molybdenum) for different weigth concentrations.

The $\mathrm{Al}-\mathrm{Cr}-\mathrm{Ni}$ and $\mathrm{Al}-\mathrm{Mn}-\mathrm{Ni}$ systems were corresponding to an objective of lower cost resulting from an improvement of workability of the alloys. For the Al - Cr - Ni system the chemical compositions investigated would give informations in regard to the influence of Nickel content and of the addition of Molybdenum. For the Al - Mn - Ni system the selected chemical compositions were corresponding to an increase of the alloying elements' content as compared to what has already been done by RAUFOSS and to a study of the effect of the Manganese - Nickel ratio.

Extremely fine powders from the 12 compositions were produced by ALPOCO by Inert Gas Atomization. The size range of the powders was very narrow, the majority of the powder particles being in the range $10-50 \mu \mathrm{m}$ with the mean size being $20-25 \mu \mathrm{m}$. The impurity levels were very low : $0,1-0,2 \mathrm{wt} . \%$.

The powders were then uniaxially cold compacted by IMPERIAL COLLEGE. The compact densities obtained vary greatly from powder to powder, with an inverse proportionality with powder microhardness. It has been found that for a good induction heating response the compact density must be in excess of $85-90 \%$. Most of the alloys compacted with a pressure of $700 \mathrm{MPa}$ were in that case and adequate heating times were achieved. The Al-Fe-V alloys, compacted at $500 \mathrm{MPa}$, had reasonable compaction densities, though the heating response was not ideal.

With the exception of the Al-Mn-Ni alloys, all the alloys could be extruded to yield continuous lengths of fully consolidated engineering materials, with an acceptable surface integrity. With a maximum permissible extrusion pressure of $1700 \mathrm{MPa}$ all the alloys could be extruded with an acceptable production rate and extrusion ratio at temperatures below $480^{\circ} \mathrm{C}$. Unfortunately the extremely brittle nature of the Al-Mn-Ni alloys led to severe cracking of the extrudates during the post extrusion water quench, making it extremely difficult (impossible in the case of Al-10Mn-6Ni alloy) to produce continuous lengths of material.

The $14 \mathrm{~mm}$ diameter extruded rods were then dispatched to the different partners to carry out the following investigations in comparison with 8009 and 8019 alloys :

- microstructural thermal stability up to $350^{\circ} \mathrm{C}$

- tensile tests at $20,250,300 \& 350^{\circ} \mathrm{C}$ on the as extruded material

- tensile tests at $20,250,300 \& 350^{\circ} \mathrm{C}$ after 1000 hours conditioning at temperature 
- short rod fracture toughness at room temperature

- creep tests at $300^{\circ} \mathrm{C}$ under $150 \mathrm{MPa}$

- corrosion

\section{COMPARISON OF THE DIFFERENT ALLOY SYSTEMS}

The microstructural investigations conducted by CENIM on the extruded rods before and after conditioning at elevated temperature evidence a fine homogeneous microstructure, with a structure of elongated powder particles coming from the extrusion, except for the Al-Fe-Mo system for which some undeformed spherical and some cracks could be observed.

The microstructure is not altered after a 1000 hours conditioning at $300^{\circ} \mathrm{C}$, while coarsening of the dispersoïds $\left(\mathrm{Al}_{13} \mathrm{Fe}_{4}\right.$ for the Al-Fe-V alloys, $\mathrm{Al}_{12} \mathrm{Mo}$ and mainly $\mathrm{Al}_{13} \mathrm{Fe}_{4}$, by one order of magnitude, combined with the disappearing of $\mathrm{A}_{16} \mathrm{Fe}$ metastable phase for the $\mathrm{Al}-\mathrm{Fe}-\mathrm{Mo}$ alloys, $\mathrm{Al}_{13}-\mathrm{Cr}_{2}$ and $\mathrm{Al}_{13}$ $\mathrm{Ni}$ for the Al-Cr-Ni-Mo alloys) or appearence of a new phase (not identified but which could be $\mathrm{T}$ phase) in the Al-Ni-Mn alloys occurs at $350^{\circ} \mathrm{C}$. This confirms the thermal stabilty of the different alloys at least up to $300^{\circ} \mathrm{C}$.

Tensile tests at temperature (fig. 1) and mainly creep tests (fig. 2) clearly indicate that the best alloys in regard to the objectives of the programme are from the Al-Fe-V system, and among them the best composition corresponds to $\mathrm{Al}-8,5 \mathrm{Fe}-2 \mathrm{~V}$, with a behaviour equivalent to that of 8009 alloy.

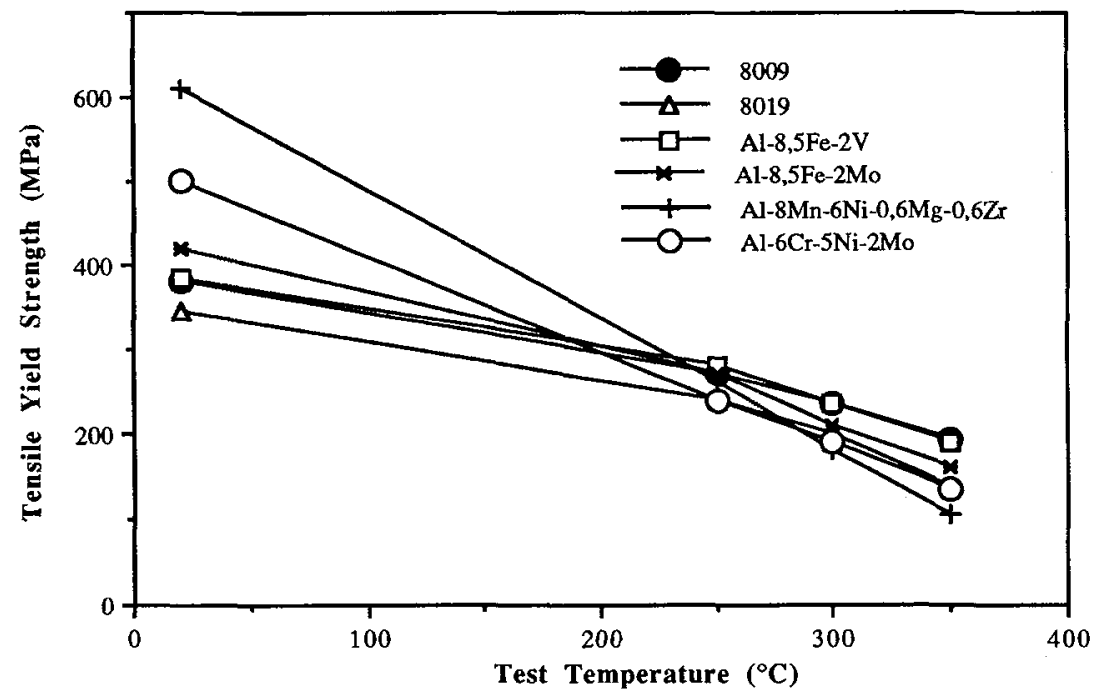

Fig. 1 - Tensile test results at temperature (following no exposure)

With the objective of an alloy that can be used at $300^{\circ} \mathrm{C}$ the creep results clearly show that the $\mathrm{Ni}$ containing alloys are not adapted at all, while they may be of interest for temperatures up to $250^{\circ} \mathrm{C}$. AlFe-Mo alloys, although they have a much better behaviour, present, as they are currently without any optimisation, too short creep rupture lives to be considered.

As far as fracture toughness is concerned only the Al-Fe-V system leads to acceptable values in regard to an objective of use on an aircraft structure (from 17 to $23 \mathrm{MPaVm}$ depending on the Vanadium content, the best corresponding to $2 \mathrm{wt} \% \mathrm{~V}$ ). Results on the Al-Fe-Mo alloys vary from 13 to $17 \mathrm{MPa} V \mathrm{~m}$ (comparable to the results obtained on 8009 samples), while Al-Cr-Ni and Al-Mn-Ni alloys appear to be very brittle with $\mathrm{K} 1 \mathrm{c}$ values below $10 \mathrm{MPa} \sqrt{\mathrm{m}}$. The SEM examination of the fracture surfaces confirms the ductile behaviour of the Al-Fe-V alloys. 


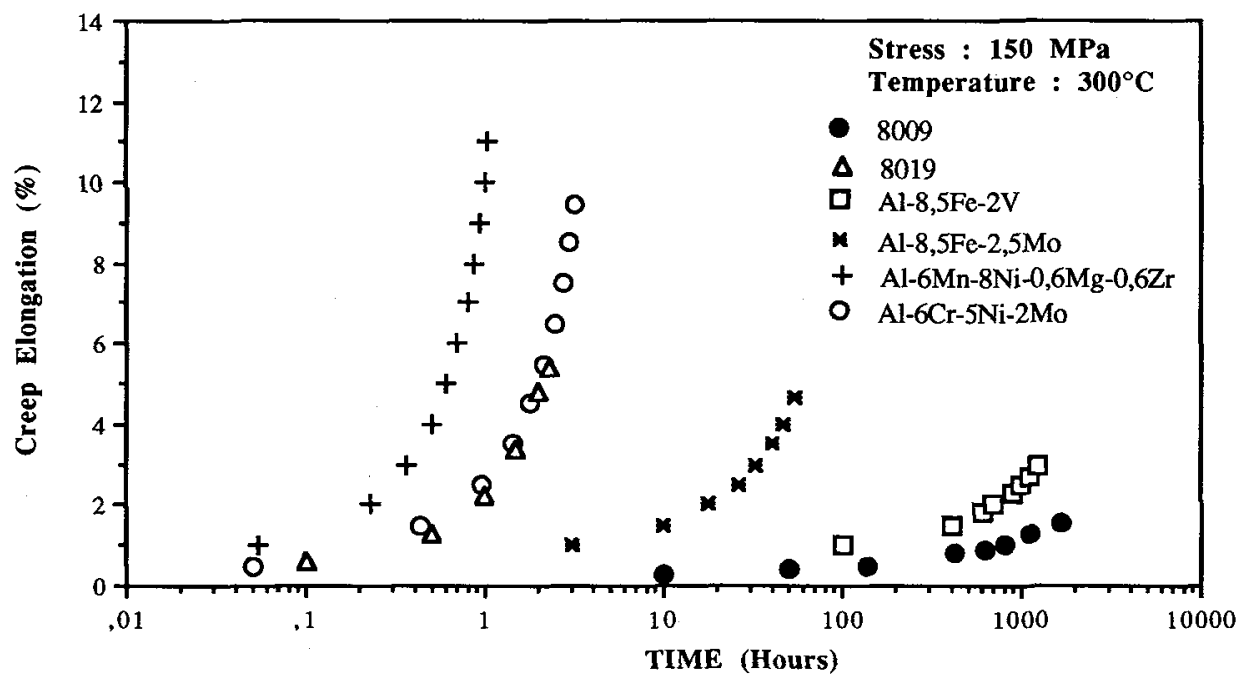

Fig. 2 - Creep results

Salt spray corrosion tests, carried out according to ASTM G 85 , evidence a slight sensitivity to intergranular corrosion, more pronounced as the alloying elements content increases. This good behaviour is rather usual with rapidly solidified materials presenting a fine homogeneous structure.

On the basis of these results it was decided to go on in the investigation of the Al-Fe-V system, and more particularly to study the possibilty of decreasing the Iron content without being detrimental to the elevated temperature performances. As a matter of fact a lower Iron content would result in a material lighter and easier to process. However, to compensate the loss of mechanical properties which may be expected from a reduction of the volume fraction of dispersoids, it was decided to combine the lower Iron content with a finer microstructure.

\section{RESULTS ON THE Al - Fe - V SYSTEM}

\subsection{Effect of the Iron content and of the powder size distribution}

Four different microstructures of powders of a $\mathrm{Al}-6 \mathrm{Fe}-1,5 \mathrm{~V}$ alloy were investigated :

- normal gas atomised powders (0 to $45 \mu \mathrm{m}$ )

- fine powders ( 0 to $30 \mu \mathrm{m})$

- mid range powders (10 to $30 \mu \mathrm{m}$ )

- coarse powders ( 30 to $45 \mu \mathrm{m})$

The powders were all atomized, compacted and consolidated into extruded rods also the same conditions as for the $\mathrm{Al}-8,5 \mathrm{Fe}-2 \mathrm{~V}$ alloy. The different size distributions were obtained by classification.

In regard to the manufacturing process the interest of a lower Fe content may be summarized as follows :

- the lower Fe content leads to softer powders and thus to compaction densities much higher (97\%)

- this greatly enhances the induction heating response (by a ratio of 2) but also gives a much better reproducibility in heating times;

- besides, extrusion pressures may be reduced by $10 \%$. 
In regard to the mechanical properties the results reported in table 1 clearly show that reducing the Iron content while removing the $>30 \mu \mathrm{m}$ size fraction leads to a strength / toughness combination exceptionally high which compares favourably with the $8,5 \mathrm{Fe}$ alloy except for the Ultimate Tensile Strength which is lower. On the other hand, removing the $<10 \mu \mathrm{m}$ size fraction only serves to soften the material with only a negligeable improvement in damage tolerance.

\begin{tabular}{|c|c|c|c|c|c|c|}
\hline $\begin{array}{c}\text { Iron content } \\
(\mathrm{Wt} \%)\end{array}$ & $\begin{array}{c}\text { Size distribution } \\
(\mu \mathrm{m})\end{array}$ & $\begin{array}{c}\text { TYS 20 } \\
(\mathrm{MPa})\end{array}$ & $\begin{array}{c}\text { TYS 300 } \\
(\mathrm{MPa})\end{array}$ & $\begin{array}{c}\text { UTS 20 } \\
(\mathrm{MPa})\end{array}$ & $\begin{array}{c}\text { UTS 300 } \\
(\mathrm{MPa})\end{array}$ & $\begin{array}{c}\mathrm{K} 1 \mathrm{c} 20^{\circ} \mathrm{C} \\
(\mathrm{MPa} \mathrm{m})\end{array}$ \\
\hline 8,5 & Full fraction & 385 & 235 & 490 & 270 & 23 \\
\hline & $0-30$ & 380 & 220 & 420 & 240 & 29 \\
6 & $10-30$ & 340 & 215 & 400 & 235 & 31 \\
& $30-45$ & 315 & 200 & 380 & 215 & 34 \\
& Full fraction & 335 & 200 & 395 & 215 & 30 \\
\hline
\end{tabular}

Table 1. Effect of the Iron content on the mechanical properties in an $\mathrm{Al}-\mathrm{Fe}-\mathrm{V}$ alloy

The $6 \% \mathrm{Fe}$ alloy, which seems very attractive, still needs to be validated by creep tests. Besides removing the $>30 \mu \mathrm{m}$ size fraction by classification is a penalty in terms of material cost; thus it has to be thought about a process which would give directly a distribution below $30 \mu \mathrm{m}$ for a very limited extra cost.

\subsection{Effect of Magnesium additions}

As reducing the Fe content results in lowering the Ultimate Tensile Strength, it was decided to carry out a limited investigation on the effect of small Magnesium addition on the strength of the Al-6Fe-1,5V alloy. As a matter of fact, theoretically the $\mathrm{Mg}$ addition would increase the tensile strength over the whole temperature range, which should allow to keep the full fraction of powders, and thus not to increase the cost.

Extruded rods in $\mathrm{Al}-6 \mathrm{Fe}-1,5 \mathrm{~V}-2 \mathrm{Mg}$ were consolidated by IMPERIAL COLLEGE from gas atomized powders with a $0-30 \mu \mathrm{m}$ size distribution, the parameters being the same as for the other alloys.

The results reported in table 2 confirmed that the addition of Magnesium leads to a very important increase of tensile strength at room temperature. Unfortunately it is accompanied by a drop in fracture toughness; besides the benefit in strength is not kept up to $300^{\circ} \mathrm{C}$.

\begin{tabular}{|c|c|c|c|c|c|}
\hline Alloy & $\begin{array}{c}\text { TYS 20 } \\
(\mathrm{MPa})\end{array}$ & $\begin{array}{c}\text { TYS } 300^{\circ} \mathrm{C} \\
(\mathrm{MPa})\end{array}$ & $\begin{array}{c}\text { UTS 20 } \\
(\mathrm{MPa})\end{array}$ & $\begin{array}{c}\text { UTS 300 } \\
(\mathrm{MPa})\end{array}$ & $\begin{array}{c}\mathrm{K} 1 \mathrm{c} 20^{\circ} \mathrm{C} \\
(\mathrm{MPa} \text { m })\end{array}$ \\
\hline $\mathrm{Al}-6 \mathrm{Fe}-1,5 \mathrm{~V}$ & 380 & 220 & 420 & 240 & 29 \\
\hline $\mathrm{Al}-6 \mathrm{Fe}-1,5 \mathrm{~V}-2 \mathrm{Mg}$ & 465 & 185 & 550 & 205 & 14 \\
\hline
\end{tabular}

Table 2 - Effect of a 2 wt\% Magnesium addition on the mechanical properties in an Al-6Fe-1,5V alloy

Because of its poor fracture toughness the Al-6Fe-1,5V-2Mg alloy is not suitable for structural applications. However its lower density combined with a good ductility, increasing with temperature, and a high strength level make it a serious candidate for non structural applications, mainly in the 150 $250^{\circ} \mathrm{C}$ temperature range.

\section{FURTHER DEVELOPMENTS}

In the objective of increasing the strength of the alloys, the interest of having a finer microstructure, in particular using a process of production of powders which would lead to a $<30 \mu \mathrm{m}$ size distribution for a limited extra cost, has already been mentioned. This objective may be reached through a modification of the gas atomization equipment, this being currently under investigation at ALPOCO.

Other possibilities exist to refine the structure and increase the strength; among them the mechanical alloying process seems very promising and its application to the $\mathrm{Al}-\mathrm{Fe}-\mathrm{V}$ compositions will be studied in the next step of this programme. 
Besides any alloy, even if it presents the best compromise of properties ever seen, is worth nothing if you cannot manufacture a part of it. Now it appears that these alloys, because they are very stable at elevated temperature, and because they present a loss of ductility around $150^{\circ} \mathrm{C}$, are very difficult to process. Thus the investigation on the manufacturing processes of theses alloys (extrusion, forging, forming of sheets ...) will also be a major concern for the next months.

\section{APPLICATIONS ON AIRCRAFT STRUCTURES}

Aside from the potential use as fuselage skin material on a new supersonic aircraft many applications of the developped alloys have been identified on existing products.

Among them can be noticed the missile fins and bases, mainly designed in stiffnes and for which a 30 to $40 \%$ weight saving may be expected, the helicopters transmission shafts, designed in fatigue strength at temperature, and some engine casings, the leading edges, air intakes, wheels and mainly the hot air conditioning tubes of subsonic aircrafts.

As a matter of fact these tubes, currently made of $\mathrm{T} 40$ Titanium, represent a significative part of the structure weight of an aircraft (about $300 \mathrm{~kg}$ on an Airbus A 340 for instance). The replacement of T 40 by an $\mathrm{Al}-\mathrm{Fe}-\mathrm{V}$ alloy might result in a weight saving of $100 \mathrm{~kg}$ per aircraft without cost penalty.

\section{CONCLUSIONS}

This European cooperation study has demonstrated that rapidly solidified Al-Fe-V alloys, because of their good thermal stability, their high specific mechanical properties and their good damage tolerance behaviour, are excellent candidates for structural applications up to $300^{\circ} \mathrm{C}$.

Among them the alloys combining a low iron content (typically $6 \mathrm{wt} \%$ ) and a fine microstructure present the best compromise in terms of strength / toughness / manufacturability.

Further developments are however needed to assess the industrial fabrication of parts, using the conventional processes such as extrusion, forging or forming of sheets, at an acceptable cost.

Potential applications on existing aircrafts have been identified which should result in significant weight savings without cost penalty.

\section{Ackowledgements}

We would like to thank the CEC DG XII for its support and our colleagues from DASSAULT AVIATION, BRITISH AEROSPACE, AlENIA, IMPERIAL COLlEGE, CEREM, ALPOCO, RAUFOSS A/S, CENIM AND THE UNIVERSITY OF PISA for their kind collaboration.

\section{References}

1. Brite Euram contract BREU 356C "New High Temperature Aluminium Alloys Development"

2. EHRSTROM J.C., Thesis Final Report

3. TORRALBA M.et al., Proceedings of the International Conference on Light Metals, Amsterdam, 20-22 June 1990

4. GILMAN P.S., Proceedings of the International Conference on PM Aerospace Materials, Lausanne, 4-6 November 1991

5. JATKAR A.D. et al., Proceedings of the International Conference on PM Aerospace Materials, Lausanne, 4-6 November 1991

6. GARDINER R.W. et al., Materials Science \& Technology, May 1991, vol.7, pp.410-418

7. Technical notes from RAUFOSS A/S 